\title{
GEOPHYSICAL AND LABORATORY STUDIES OF THE SPREAD AND QUALITY OF THE ODUKPANI LIMESTONE DEPOSIT
}

\author{
Akpan, A.E., T.E. Chidomerem and I.O. Akpan \\ Department of Physics, University of Calabar, Cross River State, Nigeria
}

Received 2010-09-20; Revised 2014-05-09; Accepted 2014-06-20

\begin{abstract}
The Odukpani limestone deposit has been investigated using geophysical and laboratory techniques with the aim of generating information on its spread and quality. Information generated from the analyses of twenty-six Vertical Electrical Soundings (VES) and core drilling data were used in the study. The VES data were acquired in both grid and random patterns in the immediate area of the limestone mineralisation and the adjoining areas using the Schlumberger array was adopted in acquiring the VES data in both grid and random patterns in the limestone mineralized and the adjoining areas. Cored limestone samples were analysed using the Proton Induced X-ray Emission (PIXE) method in order to determine their elemental composition and consequently quality. Both manual and computer modeling techniques were used in modeling the VES. Results show that the limestones have limited spread and have high concentration of $\mathrm{Ca}(11,200 \%)$ and $\mathrm{K}(302,400 \%)$. Mean electrical resistivity of the limestone horizon is $405 \Omega \mathrm{m}$ which is suggestive of a limestone deposit that is not pure but contaminated with $\mathrm{Fe}$ $(8,620 \%)$, shaly and other contaminants. The limestone deposit is limited in both vertical and lateral extents. Thus the deposit will not favor any large scale mining operation and equipment deployed for its exploitation must be corrosion resistant type.
\end{abstract}

Keywords: Mfamosing, Limestone Deposits, Elemental Composition, Quality, Spread, Electrical Resistivity, Pixe, Minerals, Limestones, Odukpani, Geoelectric Section, Geophysical, Limestone Outcrop, Equipment, Cretaceous, Consequently

\section{NTRODUCTION}

The Cretaceous Calabar Flank sedimentary basin in southeastern Nigeria has widespread deposits of limestone in different locations like the Mfamosing, Etankpini, Odukpani, Obotme, Njagachang and Ikot Okpora deposits. These limestone deposits are currently being quarried for cement production in Mfamosing by Unicem that operates a portland cement plant in the area while little (or no) attention is given to the other deposits. Another important mineral deposit where large scale mining is also going on at different locations is barite while granite quarrying is very active in the adjoining Oban Massif. Other important economic minerals within the flank and the adjoining Oban Massif have been reported by (Akpan et al., 2010; Onyeagocha, 1986; Rahman et al., 1988; CRSG, 1989; Edet, 2004).

A large pool of geological information about any mineral including limestone exist and can be obtained in relevant government agencies and Geology Department, University of Calabar, Calabar-Nigeria. Some of these mineral deposits have never been given any geophysical investigation and consequently, information about their spread is not available. The deposits that have received proper geophysical attention are the Mfamosing and Obotme deposits (CCCL, 1975; Adeleye and Fayose, 1978; Petters and Reijers, 1997; 1987; Ekwere et al., 1994; Chidomerem, 2004). Corresponding Author: Akpan, A.E., Department of Physics, University of Calabar, Cross River State, Nigeria 
Limited confidence in geological information alone by prospective investor do not always allow many them to invest their hard earned resources even though many have at different times expressed interests in these deposits. The additional information that may convince investors can come from geophysical and laboratory investigations.

Geophysical and geological information can offer satisfactory explanations to questions bothering on availability and spread while most laboratory results can provide satisfactory explanations on questions that bother on quality. Consequently, we deploy both geophysical and laboratory techniques to investigate the spread and quality of the Odukpani Limestone deposit so that the information gap can be bridged. Our approach involved integrating available geological data generated from core drilling with information from electrical resistivity and analysis of samples using Proton Induced X-ray Emission (PIXE) of nuclear technique (Obiajunwa and Nwachukwu, 2000; Pwa et al., 2002; Arshad et al., 2007).

It is our hope that our study that is aimed at:

- Mapping the spread of the Odukpani limestone deposit

- Determining the elemental composition of the limestone deposits and consequently, the quality of the limestone

- Comparing the elemental compositions of the Odukpani limestone with that from other deposits within the flank especially the Mfamosing Limestone where commercial quarrying is ongoing

- Contributing to the development of the solid mineral sector in the Nigerian economy and finally

- Generating subsurface information that can be useful for the construction of safe engineering structures in the area

- Will bridge the existing information gap about the spread and quality of the Odukpani limestone deposit

\subsection{Location and Geology of the Study Area}

Odukpani is located between longitudes $8.15^{\circ} \mathrm{E}$ and $8.30^{\circ} \mathrm{E}$ and latitudes $5.00^{\circ} \mathrm{N}$ and $5.10^{\circ} \mathrm{N}$ in Odukpani local government area of Cross River State,
Nigeria. The Calabar-Ikom road is the major access road that connects the area to the other parts of the world. A bush path located at about $1 \mathrm{~km}$ from Odukpani junction leads to the first major limestone outcrop.This outcrop is about $80 \mathrm{~m}$ from the CalabarIkom road. Boreholes where core samples were obtained are located at the vicinity of the major outcrops.

The area has considerable relief and very thick vegetation as should be expected of any tropical rain forest setting. Some of the slopes are very steep with gullies cut by recurrent rains at the downward side. Majority of the elevated areas comprises marl, limestone hills while clays and shale's occupy the lowland areas (Fayose, 1978). Southward flowing rivers (Cross, Calabar and Qua) and a network of streams many of which are seasonal drain the area.

The area has a tropical climate made up of two seasons-wet season (April to October) and dry season (November to March).

Odukpani is located in the Calabar Flank sedimentary basin of southeastern Nigeria (Fig. 1). The lithostratigraphic development of the flank appears to have been controlled by vertical movement of faulted blocks (the Ituk High and Ikang Trough) and their associated transgressive and regressive phases (Ekwueme et al., 1995). Deposition of fluvio-deltaic clastics (of early Cretaceous (Aptian?)) on a prograding deltaic margin marks the beginning of sedimentation on the Precambrian crystalline basement complex of the Oban Massif.

The fluvio-deltaic sediment is called Awi Formation (Adeleye and Fayose, 1978). The Mfamosing Limestone was deposited on top of the Awi Formation in the mid Albian times as a product of first marine transgression. In the Albian times, the Ekenkpon Shales were deposited uncomfortably on top of the carbonate rocks of Mfamosing Limestone. This thick shale unit is characterized by minor intercalation of marls, calcerous mudstones and oyster beds (Nyong and Ramanathan, 1985). A nodular and basally shaly marl unit unit-New Netim Marl overlies the Ekenkpon Shales (Ekwueme et al., 1995). A shale unit that is interbeded marlstones and gypsum called Nkporo Formation (late Campanian-Maestrichian) uncomformably overlies the New Netim Marls (Reyment, 1965). A pebbly sandstone unit of the Tertiary Benin Formation overlies the Nkporo Shale. 


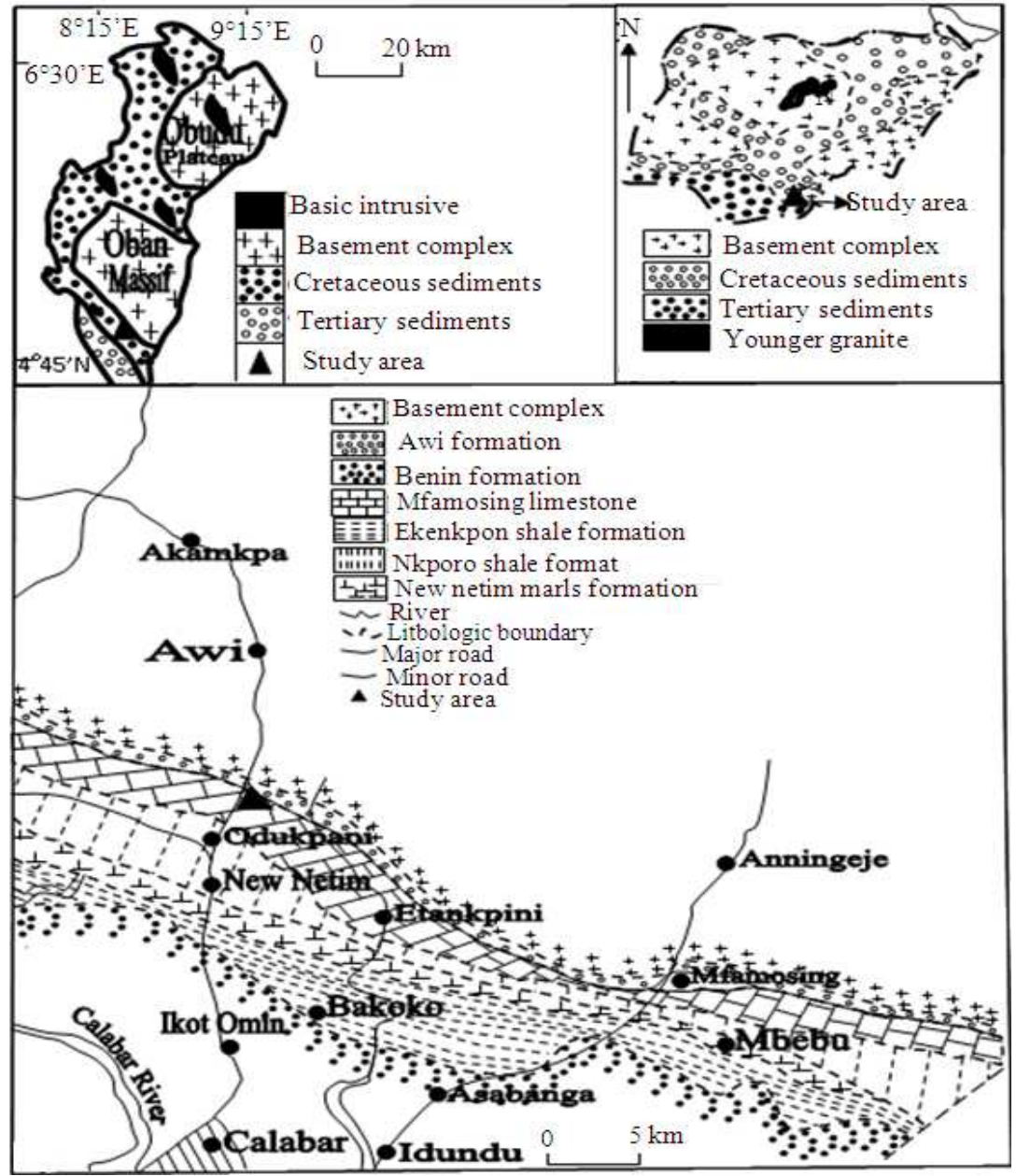

Fig. 1. Flank sedimentary basin of southeastern Nigeria

\section{MATERIALS AND METHODS}

\subsection{VES Data Acquisition and Analysis}

Sixteen Vertical Electrical Soundings (VES) utilizing the Schlumberger electrode array were executed in the area of major outcrops and the immediate surroundings in a grid pattern (Fig. 2) while ten VES sounding were made outside the immediate vicinity of the Odukpani limestone outcrops but within the same geologic province. A SAS1000 model of ABEM terrameter was the instrument used for field data acquisition. Maximum current electrode separation varied from 300-800 $\mathrm{m}$ depending on accessibility, very rugged topography and other field limiting conditions. Adequate and necessary precautionary measures were taken to ensure adequate results.
Preliminary interpretation of all the VES data was done using conventional manual curve matching and auxiliary point techniques (Zohdy et al., 1984; 1965). Computer modeling techniques (forward and inverse) were employed to model the data. Model VES curve obtained from the limestome enriched area is shown in Fig. 3a and b. Geoelectric sections were constructed to access the spread of the various lithologic units along NE-SW and NW-SE (geologic strike) directions and results obtained are shown in Fig. 4 and 5. Inserted in the geoelectric sections are borehole data that were used to access the extent of correlation between borehole and geologic data.

Thickness of a geoelectric layer that was identified to be a limestone layer was contoured using graphic software (surfer 8) (Fig. 6). 
Akpan, A.E. et al. / American Journal of Environmental Sciences 10 (4): 347-356, 2014

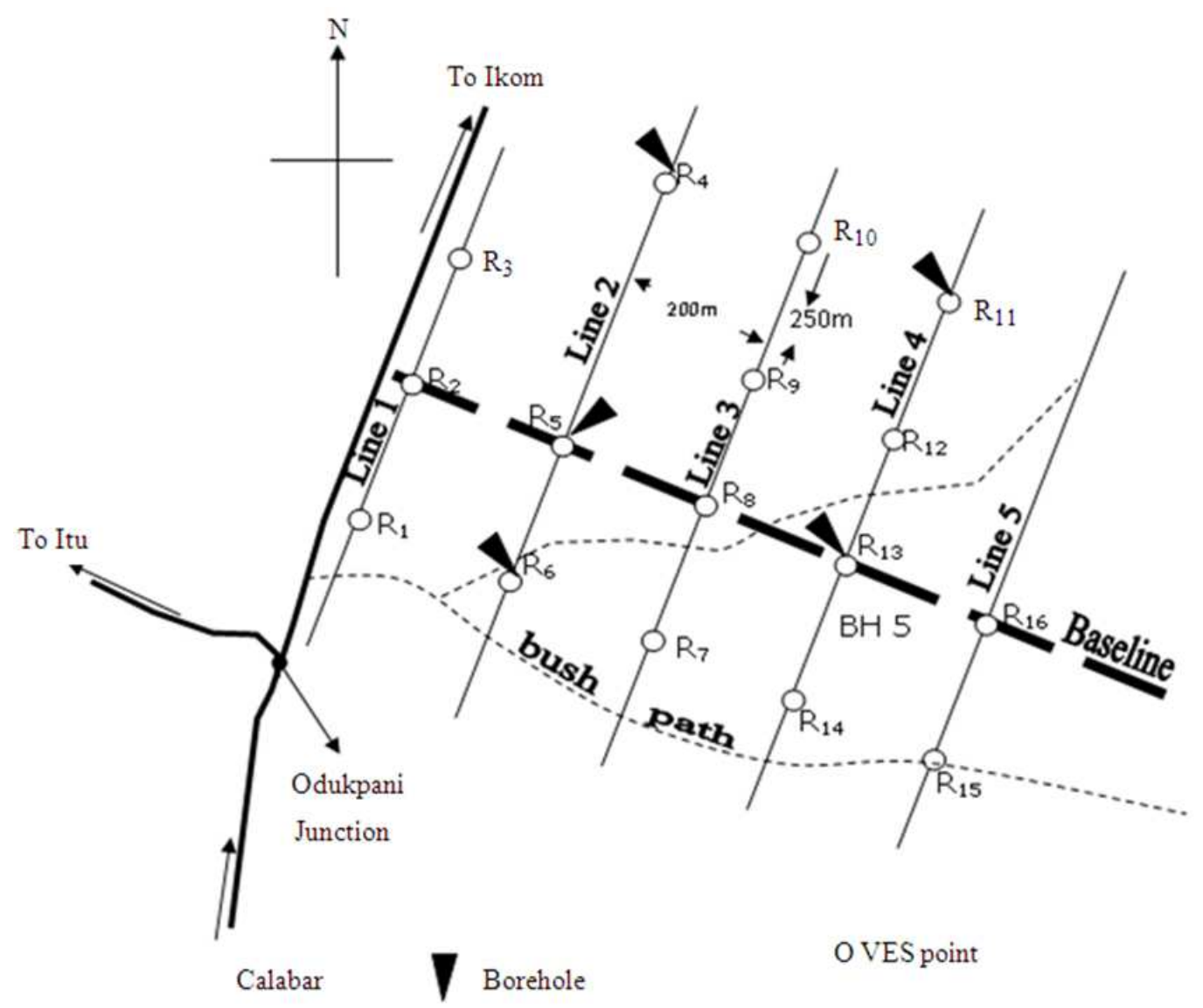

Fig. 2: Grid plan showing some VES sounding stations and borehole locations

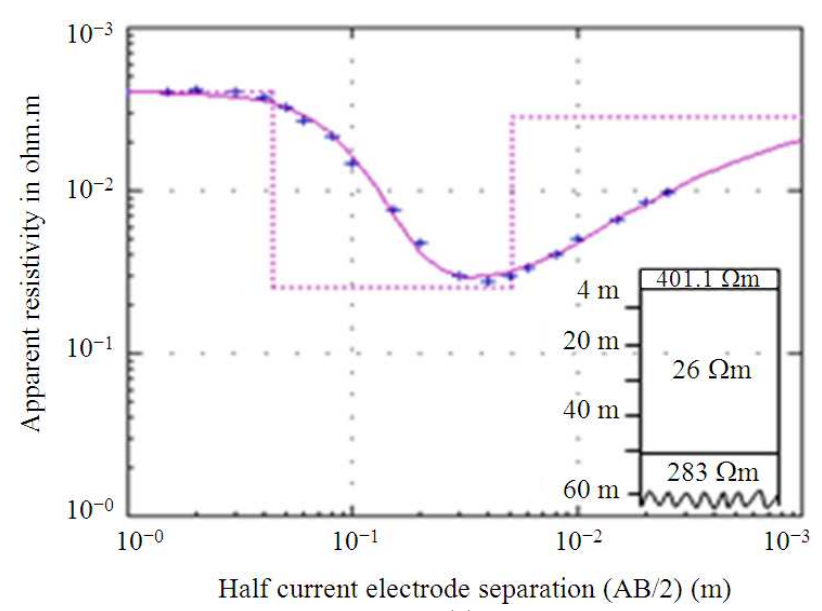

(a)

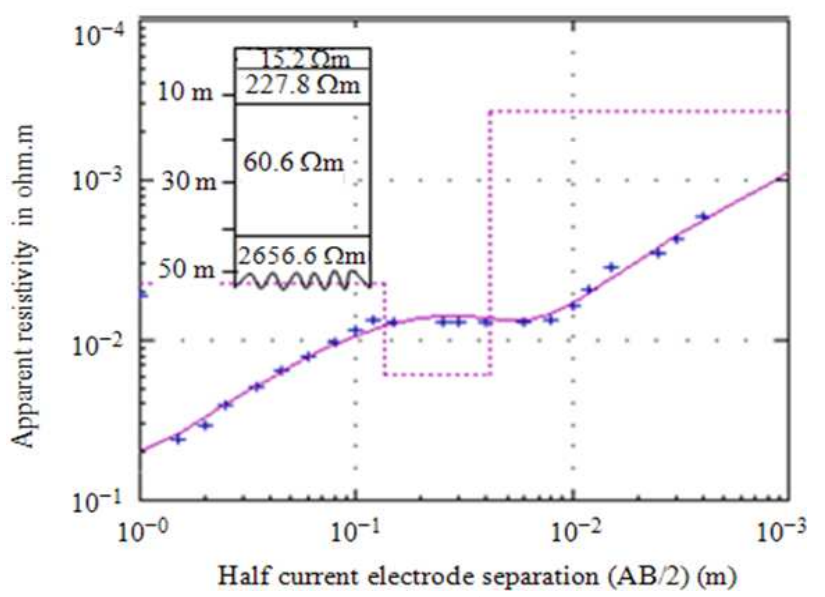

(b)

Fig. 3. A modeled VES curve obtained from the limestone enriched parts of the study area. Insert: A 1D geoelectric section of the modeled result 


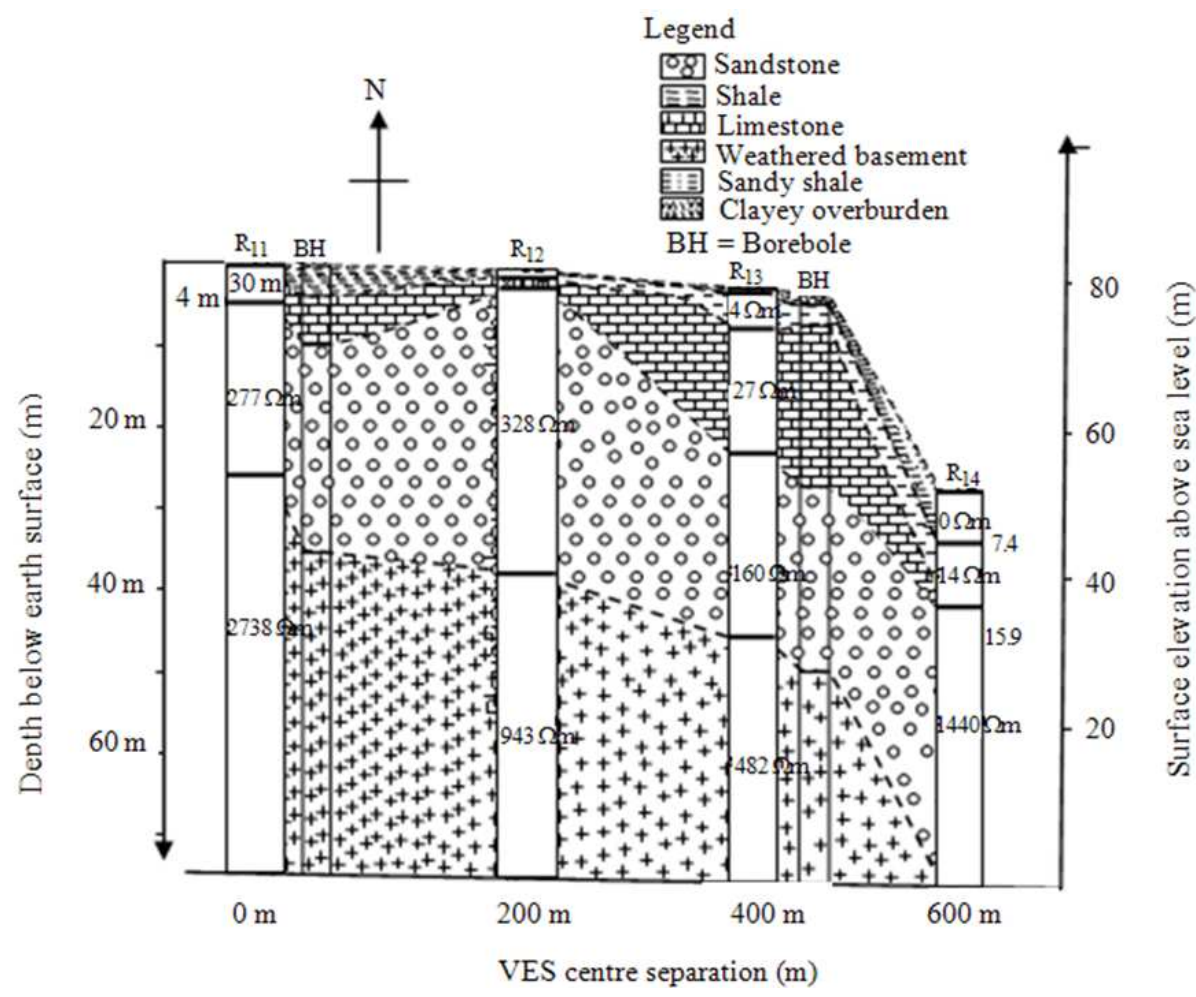

Fig. 4. A geoelectric section along Line 4

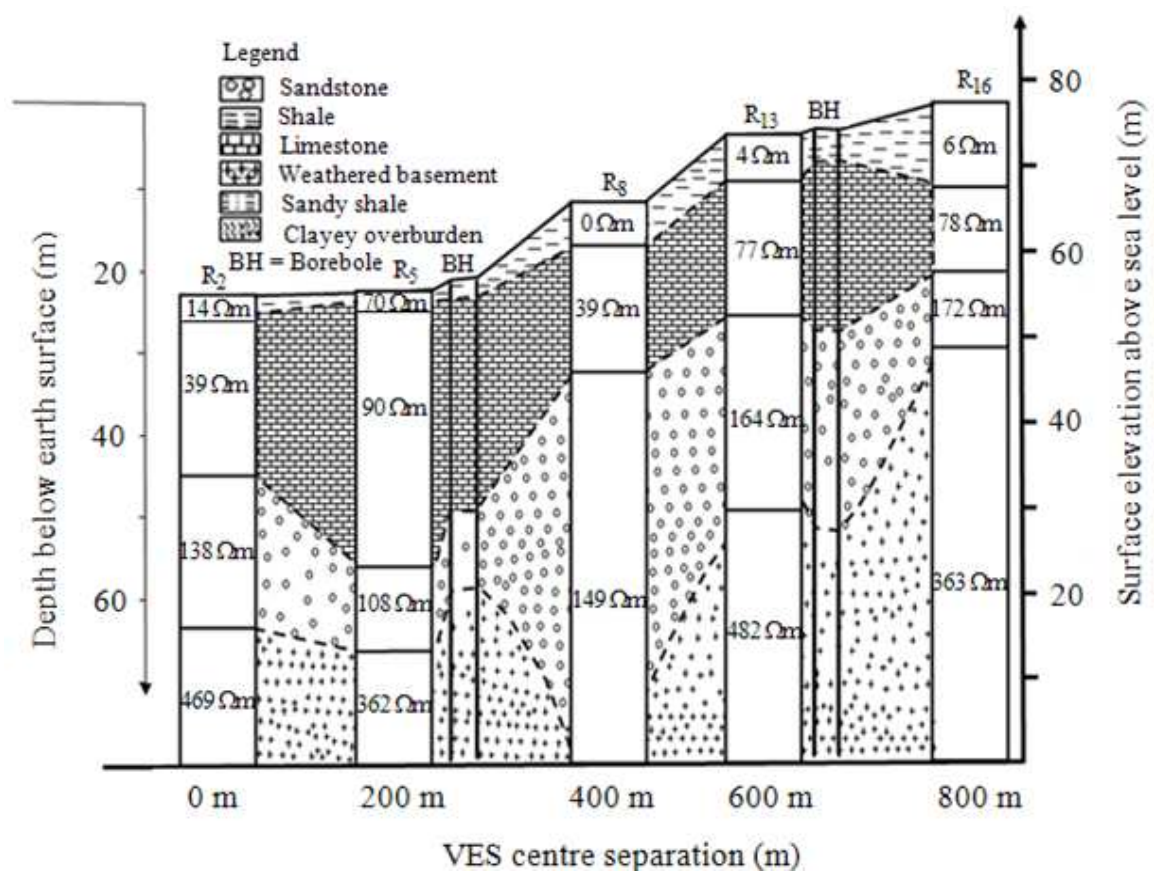

Fig. 5. A NE-SW Geoelectric section along baseline (strike) 
Akpan, A.E. et al. / American Journal of Environmental Sciences 10 (4): 347-356, 2014

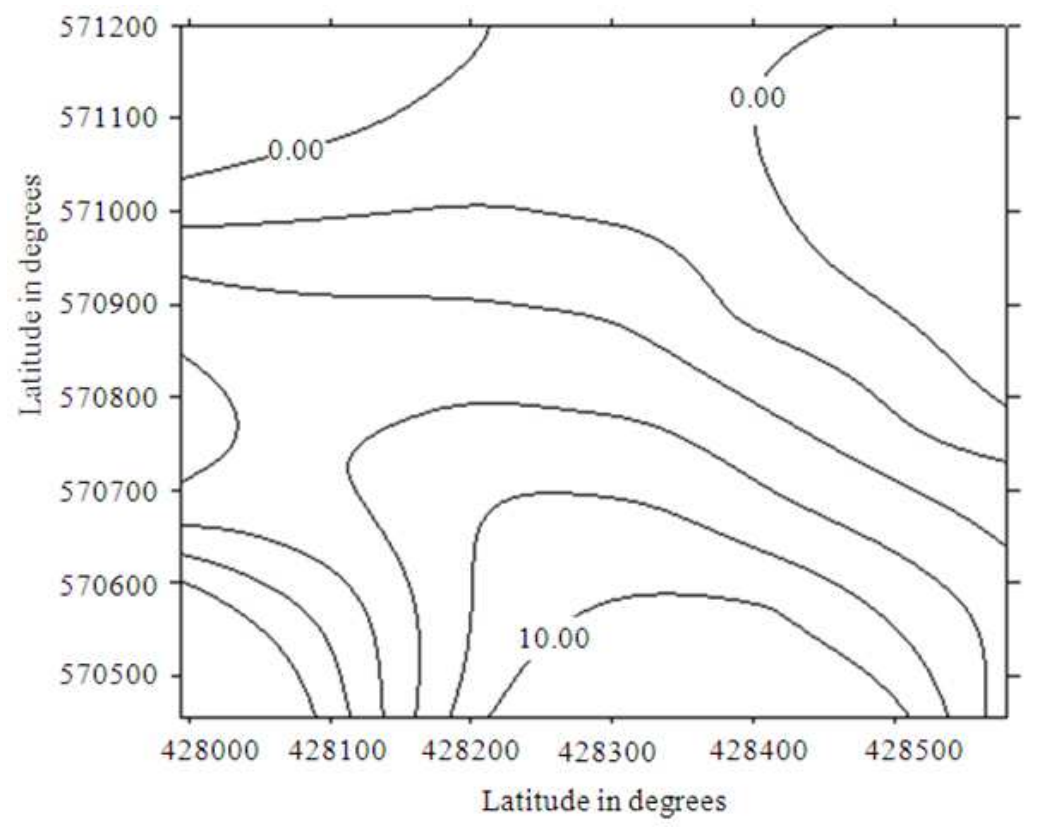

Fig. 6. Thickness of a geoelectric layer that was suspected to be limestone layer

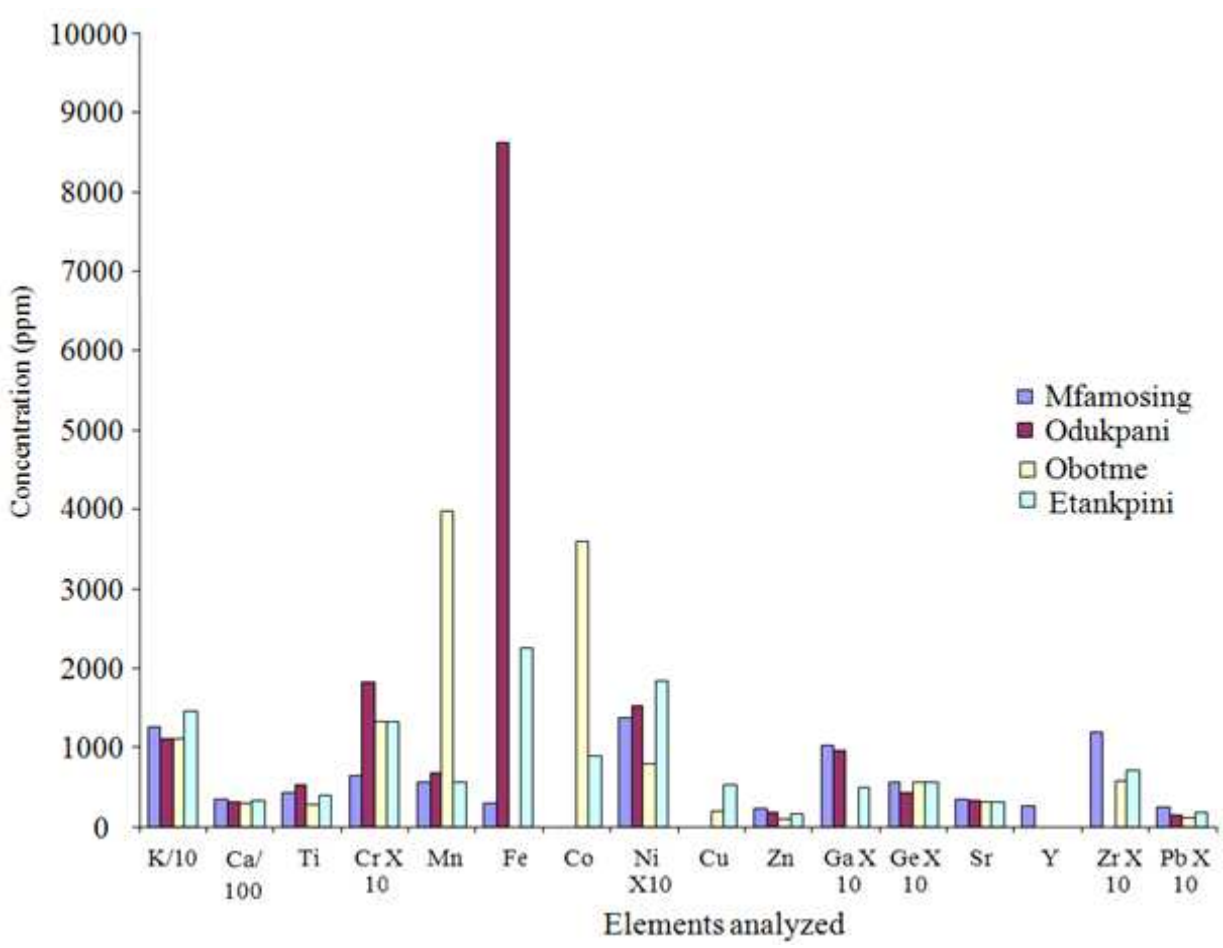

Fig. 8. Distribution of some major elements in some limestone samples from the Calabar Flank sedimentary basin (Concentration of some elements have either been reduced or amplified by the factors indicated in the chart to enable the data to be plotted) 


\subsection{Limestone Sample Collection and Analysis}

Core and outcrop samples of the limestone were randomly collected at different locations within the area. These core samples and other samples collected from other limestone deposits within the flank (Mfamosing, Obotme and Etankpini) were analyzed for elemental composition using the Proton Induced X-Ray Emission (PIXE) method at Centre for Energy Research and Development (CERD), Obafemi Awolowo University Ile Ife, Nigeria. The ion-beam facility consists of a $1.7 \mathrm{MV}$ Tandem accelerastor complete with and end station. Signals generated from the accelerator were passed to a counter and later a network of computers for analysis and display of the PIXE spectrum (Fig. 7). Precautionary measures were taken to obtain reliable results included the recalibrating of the $\mathrm{Si}(\mathrm{Li})$ detected by analyzing a standard sample (Akpan et al., 2010; Amodu, 2010). Mean results obtained are presented in the bar chart shown in Fig. 8.

\subsection{Interpretation and Discussion of Results}

\subsubsection{Interpretation}

Most of the sounding curves were HK and KHK type depicting a 3-4 layered subsurface structure. The first and third layers of the $\mathrm{HK}$ curves are more resistive than the second layer $\left(\rho_{1}>\rho_{2}<\rho_{3}\right)$ while for the KHK curves, the second and fourth layers are more resistive than the first and the third layers $\left(\rho_{1}<\rho_{2}>\rho_{3}<\rho_{4}\right)$. The first layer is suspected to either be a clayey layer or limestone layers with resistivity that ranges from 1.0-4.0 $\Omega \mathrm{m}$ (mean of $7.5 \Omega \mathrm{m}$ ). Variation in the resistivity of this layer is suspected to be indicative of the degree of moisture content of the layer at that point. Thickness of this layer varies from $0.6 \mathrm{~m}$ at $\mathrm{R}_{12}$ to $9.8 \mathrm{~m}$ at $\mathrm{R}_{16}$ (mean of $4.1 \mathrm{~m}$ ).

Results from $R_{1}, R_{6}, R_{7}, R_{14}$ and $R_{15}$ stations suggest that the electrical resistivity of the second layer to varies from 14.0-22.0 $\Omega \mathrm{m}$ (mean of $18.0 \Omega \mathrm{m}$ ). Shaly materials were inferred to be the dorminant subsurface materials at these stations while at stations $\mathrm{R}_{2}, \mathrm{R}_{3}, \mathrm{R}_{5}, \mathrm{R}_{8}, \mathrm{R}_{9}, \mathrm{R}_{13}$ and $\mathrm{R}_{16}$, the electrical resistivity varies from 30.0-780.0 $\Omega \mathrm{m}$ (mean of $405.0 \Omega \mathrm{m}$ ) and limestone materials was inferred to be the dominant subsurface materials. Thickness of this layer varies from $1.2 \mathrm{~m}$ at $\mathrm{R}_{12}$ to $36.5 \mathrm{~m}$ at $\mathrm{R}_{10}$ (mean of $18.0 \mathrm{~m}$ ). The third layer at stations $\mathrm{R}_{2}, \mathrm{R}_{3}$, $\mathrm{R}_{5}, \mathrm{R}_{7}, \mathrm{R}_{9}, \mathrm{R}_{12}, \mathrm{R}_{13}, \mathrm{R}_{15}$ and $\mathrm{R}_{16}$ have electrical resistivity values varying from 153.0-538.0 $\Omega$ m (mean of 345.5 $\Omega \mathrm{m})$ and sandstone materials were inferred. This layer was not observed at $\mathrm{R}_{4}, \mathrm{R}_{10}, \mathrm{R}_{11}$ and $\mathrm{R}_{12}$ stations possible because it might have thinned out and so became suppressed. At $\mathrm{R}_{4}, \mathrm{R}_{10}, \mathrm{R}_{11}$ and $\mathrm{R}_{12}$ stations, the third layer was equivalent to the fourth layer in other sounding stations except at $\mathrm{R}_{8}$ and $\mathrm{R}_{14}$ stations.

Resistivity of the third layer at $\mathrm{R}_{8}$ and $\mathrm{R}_{14}$ stations varies from 137.0-2738.0 $\Omega \mathrm{m}$ (mean of $1437.5 \Omega \mathrm{m}$ ) and was suspected to be some weathered (and/or fractured) basement materials. At $\mathrm{R}_{6}$ and $\mathrm{R}_{14}$ stations, resistivity of the fourth layer is 144.0 and $149.0 \Omega \mathrm{m}$ (mean of 146.5 $\Omega \mathrm{m})$ respectively and it was interpreted to be a sandstone layer. Thicknesses of the last geoelectric layers could not be determined from the field data.

In the VES stations outside the gridded area, no evidence of limestone occurrence was noticed in any of the sounding curves. Rather the curves show evidence that thick shale, marl and some sandstone as major subsurface sediments. The interpreted results agree reasonably well with the geology and the lithologic logs from the area, which were used as control.

\section{RESULTS AND DISCUSSION}

Limestone is not uniformly distributed in the area studied. At sounding stations $\mathrm{R}_{1}, \mathrm{R}_{4}, \mathrm{R}_{10}, \mathrm{R}_{11}, \mathrm{R}_{14}$ and $\mathrm{R}_{15}$ located along the geologic strike line, no limestone was detected but results from $\mathrm{R}_{2}, \mathrm{R}_{5}, \mathrm{R}_{8}, \mathrm{R}_{13}$ and $\mathrm{R}_{16}$ stations show that limestones with variable thickness are present.

Though limestones are the major minerals of economic importance in the area, the lack of reasonable contrast between the observed electrical resistivity values of the limestone enriched areas and the inter-fringing shales (and/or marls) that underlie the limestones suggest that the limestones do not have large vertical extent (Ekwere et al., 1994; Okereke et al., 1998). This observation is supported by information from borehole logs and it suggests that the limestones are either mixed with shaly substances or are contaminated with other conducting substances like Fe. Presence of the element $\mathrm{Fe}$ in most mineral resources in this area has been reported by several authors including (Fayose, 1978; Petters and Reijers, 1997; 1987; Jauro et al., 2008; Akpan et al., 2010; 2011; Amodu, 2010). Higher concentration of $\mathrm{Fe}$ in minerals is actually an undesirable because high inhalation from cement dust can lead to the development of benign pneumoconiosis called siderosis. It also enhances the risk of lung cancer (Jauro et al., 2008; Lenntech, 2008).

The low resistivity values of the limestones may either be a pointer to its present state or have clay filled solution channels. Water from heavy rains (that characterized the area) and other surface water sources might have dissolved parts of the limestone to form a 
weak carbonic acid. This acid though weak appears to be a dominant factor in the weathering of the limestones.

The concentrations of elements in the samples are variable with $\mathrm{Ca}$ and $\mathrm{K}$ topping the concentration chart while the concentration of $\mathrm{Pb}$ and $\mathrm{Zn}$ were the least. This is indicative of a high quality dolomitic limestone. The low concentration of $\mathrm{Pb}$ and $\mathrm{Zn}$ is a healthy development considering their potential negative environmental and health effects when mining of the limestone begins. Mudel et al. (1996) has discussed the potentials of some trace elements like boron, lead, arsenic and son on to contaminate both surface and groundwater in an area.

The limestones are not massively bedded but rather are shallow surfacial structure that pinches out rapidly towards the Calabar-Ikom road and inwards near line 1. The limestones thus have very limited extent that seems to be concentrated within a localised region. The presence of strontium implies that that the limestones were deposited at shallow depth (Adebayo et al., 2009). These observations are also evident in the geoelectric sections drawn from the geophysical results (Fig. 4 and 5). It is thickest near $\mathrm{R}_{5}$ VES point. The limestones are surrounded by sandstones of Awi Formation in the north and shales with some inter-fingering marls in other directions. The usual segmentation of many limestone deposits into horizons (Omatsola and Adegoke, 1981; Ekwere et al., 1994; Petters and Reijers, 1997; Badmus and Ayolabi, 2005; Badmus and Olatinsu, 2009) was not reasonably observed and this could be attributed to the location of the deposit at the fringe of the Precambrian Oban Massif where conditions might not have been favorable for many microorganisms to survive (Adebayo et al., 2009).

The $\mathrm{Ca}$ and $\mathrm{K}$ contents of the limestones are very high and compares favorably with the limestone deposits at Mfamosing where large scale quarrying is going on (Figs 7 and 8). The quality of the Odukpani limestone appears to be lower than what is obtainable at the Mfamosing Limestone deposit where one of the best quality limestones in the world is being mined (Ekwueme, 1985; Petters and Reijers, 1987) (Fig. 8). The observed reduction in the industrial quality of the limestones can be attributed to the high Fe content observed in the PIXE results. The Fe might have either migrated from the shales of the adjacent Ekenkpon Shales or from the adjoining Oban Massif (Ekwueme, 1985; Petters and Reijers, 1987; Edet, 2004). The high Fe contents of the limestones suggest that all mining tools and other valuable machinery that are designated for its exploitation must be carefully selected to avoid intermittent breakdown as a result of contact with ferruginous substances (Amodu, 2010).

The spread of the limestones will not favour large scale mining operation. Consequently, low scale mining using low rated equipment might be most suitable and economical option.

\section{CONCLUSION}

Limestones are the major minerals of economic importance that exist at the location of the Odukpani limestone deposit. The limestones are not massively bedded but are rather near surface structures that thin out as Calabar-Ikom road is approached and also thins out as the thick bush is approached. Variations in the thickness of the limestone are not systematic since there is no clear evidence of it being segmented into horizons.

The concentrations of $\mathrm{Ca}$ and $\mathrm{K}$ in the limestones are very high and are indicative of a good quality limestone deposit worth investing though are contaminated with different forms of impurities like Fe. The low resistivity values obtained in the area are suspected to be caused by the present weathered state of the limestones, high shale and $\mathrm{Fe}$ contents. Thus any equipment that is to be deployed in the area should be carefully selected.

The spread of the limestone deposit will not economically favorable to the deployment of highly rated mining equipment. Consequently, lowly rated equipment may be the optimum choice for its exploitation.

\section{ACKNOWLEDGEMENT}

We wish to acknowledge the valuable contributions of late Prof. E. W. Mbipom whose encouragements, moral and financial supports helped us greatly in this study. The contributions of the anonymous reviewers are also acknowledged.

\section{REFERENCES}

Adebayo, P.O., A.O. Falana and O.A. Adeagbo, 2009. Geochemical composition: Indicator of depositional environment and industrial quality of ewekoro limestone sagamu, Nigeria. Proceedings of the 45th International Conference on, Book of Abstracts of Nigerian Mining and Geosciences Held in Owerri, Nigeria, (MGHO" 09).

Adeleye, D.R. and E.A. Fayose, 1978. Stratigraphy of the type section of Awi formation, Odukpani area, Southeastern Nigeria. Nig. J. Mining Geol., 15: 33-37. 
Akpan, A.E., E.E. Ukwang and E.O. Esu, 2011. Assessment of the potentials of some engineering materials in parts of Akamkpa, southeastern Nigeria. J. Min. Geol., 40: 113-119.

Akpan, I.O., A.E. Amodu and A.E. Akpan, 2010. Elemental analysis of limestone samples from Obajana and mfamosing limestone deposits, Nigeria, using nuclear techniques. J. Environ.. Sci. Tech., 4: 332-339. DOI: 10.1016/j.apradiso.2011.03.038

Amodu, A.E., 2010. The use of nuclear technique for elemental analysis of limestone in parts of Nigeria. M.Sc. Thesis, University of Calabar, Calabar, Nigeria.

Arshad, M.K.M., A. Jalar, I. Ahmad and G. Omar, 2007. The characterization of al bond pad surface treatment in Electroless Nickel Immersion Gold (ENIG) deposition. Am. J. Applied Sci., 4: 133-141. DOI: 10.3844/ajassp.2007.133.141

Badmus, B.S. and E.A. Ayolabi, 2005. Litho-facies changes in ewekoro limestone using schlumberger geoelectric sounding techniques. Nig. J. Applied Sci. Technol., 10: 42-52.

Badmus, B.S. and O.B. Olatinsu, 2009. Geoelectric mapping and characterization of limestone deposits of Ewekoro formation, Southwest. Nigeria. J. Geol. Min. Res., 1: 8-018.

CCCL, 1975. Limestone deposits in Etankpini and Mfamosing: An Unpublished geological survey report. Calabar Cement Company Limited.

Chidomerem, T. E., 2004. Geophysical investigation of the Odukpani limestone deposit using the vertical electrical sounding technique, southeastern Nigeria. M.Sc. Thesis. University of Calabar, Calabar, Nigeria.

CRSG, 1989. Report on preliminary investigations of economic mineral occurrences in Oban-Obudu basement complex. Cross River State Government.

Edet, A.E., 2004. A preliminary assessment of the concentrations of rare earth elements in an acidic fresh groundwater (south-eastern Nigeria). J. Applied Earth Sci., 113: 100-109. DOI: 10.1179/037174504225004475

Ekwere, S.J., E.O. Esu, C.S. Okereke and E.B. Akpan, 1994. Evaluation of limestones in Obotme area, (southeastern Nigeria) for Portland cement manufacture. Nig. J. Min. Geol. 30: 145-150.

Ekwueme, B.N., 1985. The chemical composition and industrial quality of limestones and marls on the Calabar Flank, southeastern Nigeria. Nig. J. Min. Geol., 22: 51-56.
Ekwueme, B.N., E.E. Nyong and S.W. Petters, 1995. Geological Excursion Guidebook to Oban Massif, Calabar Flank and Mamfe Embayment, Southeastern, Nigeria. 1st Edn., Dechord Press, Calabar, ISBN-10: 9783235427, pp: 36.

Fayose, E.A., 1978. Depositional environment of carbonate, Calabar Flank, southeastern Nigerian. Ni. J. Min. Geol., 5: 1-13.

Jauro, A., A.A. Chigozie and M.B. Nasirudeen, 2008. Determination of selected metals in coal samples from Lafia-Obi and Chikila. Sci. World J., 3: 79-81.

Lenntech, 2008. Health effects of iron. Lenntech.

Mudel, G.M., J. Kodikara and T. McKinley, 1996. Assessing the Environmental Impact of Coal Ash Disposal. Proceedings of the 7th Australian Paper Presented at the AIE Coal Science Conference, Churchill, Victoria, (CCV" 96).

Nyong, E.E. and R.M. Ramanathan, 1985. A record of oxygen-deficient paleoenvironments in the Cretaceous of the Calabar Flank, SE Nigeria. J. African Earth Sci., 3: 455-460. DOI: 10.1016/S0899-5362(85)80088-9

Obiajunwa, E.I. and J.I. Nwachukwu, 2000. Elemental analysis of limestone samples from Ewekoro limestone deposit in southwest Nigeria. Nuclear Instruments Res., 170: 427-431. DOI: 10.1016/S0168-583X(00)00182-8

Okereke, C.S., E.O. Esu and A.E. Edet, 1998. Determination of potential groundwater sites using geological and geophysical techniques in the Cross River State, southeastern Nigeria. J. Afr. Earth Sci., 27: 149-163. DOI: 10.1016/S0899-5362(98)00053-0

Omatsola, M.E. and O.S. Adegoke, 1981. Tectonic evaluation and cretaceous stratigraphy of the dahomey basin. J. Min. Geol., 5: 78-83.

Onyeagocha, A.C., 1986. Geochemistry of metasedimentary rocks of Uwet area, Oban Massif, southern Nigeria. Geol. Rundschau, 75: 411-420.

Petters, S.W. and T.J.A. Reijers, 1987. Depositional environments and diagenesis of Albian Carbonates on the Calabar Flank, SE Nigeria. J. Petrol Geol., 10: 283-294. DOI: $10.1111 /$ j.17475457.1987.tb00947.x

Petters, S.W. and T.J.A. Reijers, 1997. Sequence stratigraphy based on microfacies analysis: Mfamosing Limestone, Calabar Flank, Nigeria. Pet. Explorat. Bull, 11: 84-99. DOI: 10.1023/A:1003089529914 
Pwa, A., R. Siegele, D.D. Cohen, E. Stelcer and J.C. Van Moort, 2002. Proton induced X-ray emission and proton induced gamma ray emission analysis in geochemical exploration for gold and base metal deposits. Nuclear Instruments Res., 170: 501-504.

Rahman, A.M.S., S.J. Ekwere, M. Azumatullah and E.E. Ukpong, 1988. Petrology and geochemistry of granitic intrusive rocks from the western parts of Oban Massif, southeastern Nigeria. J. African Earth Sci., 7: 149-157.
Reyment, R.A., 1965. Review of Nigeria's Cretaceous stratigraphy. Nig. J. Min. Geol., 1: 61-80.

Zohdy, A.A.R., 1965. The auxiliary point method of electrical sounding interpretation and its relationship to the Dar Zarrouk parameters. Geophys., 30: 55-64.

Zohdy, A.A.R., G.P. Eaton and D.R. Mabey, 1984. Application of Surface Geophysics to Groundwater Investigation. 1st Edn., Washington, United States Government Printing Office, pp: 116. 